\title{
Attitudes of Dutch Pig Farmers Towards Tail Biting and Tail Docking
}

\author{
M. B. M. Bracke • Carolien C. De Lauwere • \\ Samantha M. M. Wind · Johan J. Zonerland
}

Accepted: 25 June 2012/Published online: 8 August 2012

(C) The Author(s) 2012. This article is published with open access at Springerlink.com

\begin{abstract}
The Dutch policy objective of a fully sustainable livestock sector without mutilations by 2023 is not compatible with the routine practice of tail docking to minimize the risk of tail biting. To examine farmer attitudes towards docking, a telephone survey was conducted among 487 conventional and 33 organic Dutch pig farmers. "Biting" (of tails, ears, or limbs) was identified by the farmers as a main welfare problem in pig farming. About half of the farmers reported to have no tail biting problems in their own herd. When farmers did report problems, they most often reported figures between 1 and $5 \%$ of the animals. High incidences of tail biting were anticipated when trying to keep undocked pigs. Enrichment materials used in the conventional sector included mainly chains (52-63\% of the farms) and hanging rubber or plastic balls (22-30\%). Straw, sawdust, or wood shavings was hardly provided in conventional pig farming (2-3\%), in contrast to organic farming (88-100\% of farms). Conventional pig farmers feel a curly tail is not very important for sustainable pig farming. They consider enrichment to be less effective and tail docking to be less stressful for them and their piglets than their organic colleagues do. Pig farmers identified climate as a main risk factor for tail biting as opposed to enrichment. The objective of reducing routine tail docking requires solutions for dealing with tail biting problems at the farm level. In this process, transfer of scientific knowledge about enrichment materials and other measures to prevent and cure tail biting is critical, as is a change in farmer attitudes and awareness of the moral issues involved.
\end{abstract}

\footnotetext{
M. B. M. Bracke ( $\square)$

Researcher of animal welfare, Wageningen UR Livestock Research, Postbus 65, 8200AB Lelystad, The Netherlands

e-mail: marc.bracke@wur.nl

M. B. M. Bracke · S. M. M. Wind · J. J. Zonerland

Wageningen UR Livestock Research, Edelhertweg 15, 8219PH Lelystad, The Netherlands

C. C. De Lauwere

LEI, Hollandseweg 1, 6706KN Wageningen, The Netherlands
} 
Keywords Farmer attitudes - Organic and conventional farming · Pigs ·

Tail biting · Welfare

\section{Introduction}

Animal welfare is an important issue in today's agriculture. The former Dutch Minister of Agriculture has stated that she wanted all interventions on animals abolished by 2023 (LNV 2007) because this raises concerns about animal welfare (Weary and Fraser 2004) and about animal integrity (Bovenkerk et al. 2002; EFSA 2007a). One of the interventions is tail docking, which is routinely used in conventional pig farming around the world to prevent tail biting. It is painful for the piglets and even may cause chronic pain (Simonsen et al. 1991; Done et al. 2003; Herskin et al. 2010). Not docking tails however is also seen as negative for the welfare and health of the piglets because this may cause more severe tail biting (Thodberg et al. 2010). Tail biting is an abnormal behavior during which pigs bite or nibble on the tails of pen mates. This damages the tail of the bitten pigs and may lead to a bleeding tail which can induce cannibalism and increase the chance of infections. Besides welfare problems, this also may lead to economic losses because of a decrease in the growth of the pigs, early death, and/or the disapproval of carcasses by the slaughterhouse (EFSA 2007a). Zonderland et al. (2011) calculated an economic loss to the Dutch pig sector of about eight million Euro's annually. Surgical docking is a major strategy to prevent tail biting (Bracke et al. 2004), because it removes (most of the) tail such that less of the tail is left for other pigs to bite on, and because the tail stump becomes more sensitive such that potential victims respond more vigorously when their tails are being manipulated (Simonsen et al. 1991). Pig farmers thus probably will resist if tail docking is prohibited, especially because outbreaks of tail biting can cause health problems in victimized pigs such as abscesses, lameness, and even death due to cannibalism (EFSA 2007a) and may lead to further increase in economic losses and reduced job satisfaction for the farmers. Tail docking however is not the only measure to prevent tail biting as it is a multifactorial problem where the absence of enrichment material, lack of space, selection for lean meat, inadequate nutrition, uncomfortable climate, poor health, group size, and animal-related factors such as age, sex and tail length play a role as well (Schröder-Petersen and Simonsen 2001; Bracke et al. 2004; EFSA 2007a; Zonderland 2010; Spoolder et al. 2011). In addition, tail docking is not sufficient: tail biting also happens in docked pigs (EFSA 2007a). This means that management measures such as the provision of enrichment materials can reduce the need for tail docking. Pig farmers thus play an important role because they must be able and willing to take extra measures to prevent tail biting.

The Netherlands has a substantial pig industry. The numbers of conventional pigs living on farms was 12.3 million for the year 2010 (CBS data cited from Hopster et al. 2011, p. 14). These pigs were kept on 2951 farms raising sows and weaned piglets (average 416 sows per farm) and 5952 farms with growing/finishing pigs (992 pigs per farm). In 2010125.516 organic pigs were kept on 100 farms $(2,000$ pigs per farm; Rotgers and Visser 2011). In numbers the organic sector is small 
compared to conventional farming, but with respect to animal welfare (the attitudes in) the organic sector may serve as an example for conventional farming (Bracke 2011).

The study presented in the underlying paper aims to get a better understanding of farmer attitudes with regard to tail biting and tail docking, the risks they perceive with regard to tail biting and their willingness to take other measures besides tail docking on the farm to prevent tail biting and to get insight into the main conditions allowing them to stop the practice of tail biting.

Although the study focusses on conventional pig farming, a comparison was made as well with the opinions and experiences of organic pig farmers because tail docking is not allowed in organic farming.

\section{Materials and Methods}

A telephone survey was carried out from the end of October until half of November 2008. The questionnaire (see Appendix) was composed based on earlier workshops with farmers on this matter (Workel et al. 2007) and results from interviews with stakeholders (Zonderland and Bracke 2008). The concept of the questionnaire was tested by telephone in three pilot interviews with farm managers of experimental pig farms. The survey was carried out by a specialized marketing agency (Entrada Market Research, Wageningen).

Animal categories of interest to this study were weaned piglets, growing/ fattening pigs, and (rearing) gilts. Weaned piglets are 4-10 weeks old piglets meant for meat production. They become a growing/fattening pig or porker from 10 weeks of age (from about $25 \mathrm{~kg}$ to about $100 \mathrm{~kg}$ body weight). A rearing gilt is a 4-10 weeks old weaned piglet meant for the reproduction of (weaned) piglets and porkers for meat production. To collect information about these animals several farm types were included in this study: reproduction/sow farms for the production of (weaned) piglets for meat production, meat/growing-finishing farms raising porkers from 10 weeks of age, closed farms with both (weaned) piglets for meat production and growing/finishing pigs and breeding farms for raising gilts intended for reproduction. In the conventional pig industry, finishing farms were required to have a minimum of 500 fattening pigs and sow farms a minimum of 100 sows to participate in the randomly sampled survey.

The limits for participation were purposely set high because the larger farms will provide a better (or more realistic) representation of tail biting incidences and risk factors. Moreover these farms are the ones who will have to deal with the transition of stopping with tail docking. Organic farms that participated to this survey did not have to convey to the lower limits.

To assess whether the answers to the questions related to farm sizes, the farms were classified in four categories: "small," "average," "large" and "very large." For the conventional farms, 6 were classified as small, 186 as average, 138 as large and 127 very large. For the organic participants 18 farms were classified as small, 9 as average, and 3 as large. 
The questionnaire consisted of 76 questions (see Appendix). Mostly quantitative (closed) answer categories were used. The questionnaire was structured as follows: 17 questions about farm characteristics (such as type of farm, number of animals, breeds, number of animals per pen, farm results, and used enrichments); one question about welfare issues in the pig industry; 28 statements about attitudes of pig farmers towards tail biting and docking; 9 questions about solving tail biting problems by farmers; 9 questions about risk factors for tail biting; 6 statements about conditions required for stopping tail docking.

Agreement with statements was assessed using Likert scales (see De Lauwere et al. 2009).

Results were analyzed in SPPS 15.0.1 (SPSS 2008). Univariate analyses were done to assess difference in tail biting between animal categories and farm types.

Chi-square tests were used to examine relationships with farm type and farm size.

\section{Results}

For this study 1.292 pig farmers were contacted by phone. The response rate was $59.7 \%$. Of the respondents $487(93.5 \%)$ had a conventional farm and $33(6.3 \%)$ had an organic farm.

The distribution of farm types (Table 1) was in accordance with the national average, but the farms were somewhat larger than average. The percentage of closed and growing/finishing farms was $29.5 \%$ and $32.6 \%$ respectively. Based on statistics of the Corporation-Information Network of the LEI, participating closed farms had on average 65 sows and 653 fattening pigs more than the national average. Surveyed sow and finishing farms had respectively 142 sows and 488 fattening pigs more than the average farm.

Prevalent breeds on conventional farms were Piétrain, Danish Duroc, Yorkshire, and Toppigs crossbreds. Organic farms mostly used Piétrain pigs.

In the conventional sector the majority of the fattening and weaned pigs were housed in pens with 10-15 pigs. On organic farms prevalent group sizes were 16-30 pigs. Most conventional farmers stated that their farming results were above average. Only $1.6 \%$ said that the farm results were less than average. Of the organic farmers $45.5 \%$ reported better production than average.

Table 1 Number $(\mathrm{N})$ of conventional and organic pig farms that participated in the survey according to farm type and type of animals

\begin{tabular}{lccccr}
\hline Type of farm (type of animal) & \multicolumn{2}{c}{ Conventional } & & \multicolumn{2}{c}{ Organic } \\
& $\mathrm{N}$ & & & $\mathrm{N}$ & $\%$ \\
\hline Reproduction/sow farms (weaned piglets) & 161 & 33.1 & & 2 & 6.1 \\
Closed farms (weaned piglets and growing/finishing pigs) & 144 & 29.6 & & 17 & 51.5 \\
Growing/finishing farms (growing/finishing pigs) & 159 & 32.6 & & 14 & 42.4 \\
Breeding farms (rearing gilts) & 23 & 4.7 & & 0 & 0 \\
Total & 487 & 100 & & 33 & 100 \\
\hline
\end{tabular}


Conventional farms usually provide a chain as enrichment for pigs (52-63\% depending on farm type), rarely straw $(2.1-3.1 \%)$ or roughage $(0.0-1.9 \%)$. No enrichment at all was reported in $0.0-0.7 \%$ of the conventional farms. Organic farms most commonly used straw as enrichment material: usually in combination with other materials (88-100\%). Roughage (5.9 and $35.7 \%$ ) and chains (11.8 and $35.7 \%$ ) were used more often for fattening pigs than for weaned pigs.

No significant differences of tail biting prevalence between animal categories or farm types (conventional versus organic) were found. A trend was found that (gilt) breeding farms reported more tail biting than conventional sow farms (on average 2.2 and $1.3 \%$ respectively $p=0.05$ ).

The onset of tail biting appeared to be several weeks later in weaned breeding gilts compared to weaned pigs. Tail lengths of these animal categories differ: most farmers reported leaving one quarter of the tail in weaners and one-third of the tail in breeding gilts.

Of conventional farmers $66 \%(n=322)$ stated that they had never tried to stop tail docking. Of the farmers who had tried, $49 \%$ stated that tail biting had consequently occurred in $20 \%$ or more of the undocked animals (Fig. 2).

At the question what level of tail biting was considered severe (bite marks/ wounds/infection in one/several animals) most conventional $(28 \%)$ and organic (30\%) pig farmers responded "one animal showing a tail wound."

The respondents were also asked what were the most important problems regarding pig welfare. $15 \%$ of the conventional farmers saw no welfare problems, and $35 \%$ had no knowledge or no opinion on the subject. Of issues identified "biting" was mentioned by 8 and $9 \%$, "lack of space" by 8 and $24 \%$, and "disease" by 7 and $3 \%$ of conventional and organic farmers respectively. "Biting" included biting in tails, ears, legs, and cannibalism. Within this category the term "tail biting" was mentioned in $62 \%$ of cases and "ear biting" in $38 \%$ of cases.

Strikingly, "interference and patronizing" by consumers and citizens were also identified as pig welfare problems. Communication, too many regulations and erroneous perceptions of the public about the needs of pigs and pig husbandry were emphasized here. Within the category "other," boredom and more enrichment material was mentioned five times, as was "group housing (for sows)."

Significant differences were found between conventional and organic pig farmers in response to statements about tail biting and tail docking (Table 2). Compared to organic farmers, conventional pig farmers viewed tail docking as a necessary procedure. They perceived it as less unpleasant to perform, less painful, and more suitable to prevent tail biting than organic pig farmers. They preferred to dock all tails rather than to risk tail biting even if it would concern just one bitten pig. They believed less in enrichment material, in the problem-solving ability of the sector (to stop tail docking within 15 years), and valued a curly tail less than organic farmers did. Conventional farmers were also less likely to appreciate the efforts of colleagues to stop tail docking.

Within the conventional sector, farmers with different farm types also differed significantly on the statement "Farmers who attempt to stop docking do the sector a favor." Breeding farms significantly agreed more to the statement than sow farms, closed farms and growing/finishing farms (respectively average scores, standard 
Table 2 Responses of pig farmers to statements on tail biting and docking (Avg, average scores, SD, standard deviations, on a scale from 1 to 6 with $1=$ completely disagree and $6=$ completely agree), $N s$ not significant

\begin{tabular}{|c|c|c|c|c|c|c|c|}
\hline \multirow[t]{2}{*}{ Statement } & \multicolumn{3}{|c|}{ Conventional } & \multicolumn{3}{|c|}{ Organic } & \multirow[t]{2}{*}{$p$} \\
\hline & $\mathrm{n}$ & Avg & SD & $\mathrm{n}$ & Avg & SD & \\
\hline $\begin{array}{l}\text { Tail biting is an important welfare issue } \\
\text { for my animals }\end{array}$ & 480 & 2.6 & 1.8 & 32 & 3 & 2.1 & Ns \\
\hline $\begin{array}{l}\text { Docking is necessary to prevent tail } \\
\text { biting }\end{array}$ & 480 & 4.9 & 1.5 & 33 & 2.8 & 2 & $p<0.001$ \\
\hline $\begin{array}{l}\text { There is no other solution to prevent tail } \\
\text { biting than docking }\end{array}$ & 470 & 4.1 & 1.7 & 33 & 2 & 1.6 & $p<0.001$ \\
\hline Docking is painful for piglets & 458 & 3.1 & 1.7 & 30 & 4.4 & 1.8 & $p<0.001$ \\
\hline $\begin{array}{l}\text { Straw can prevent problems with tail } \\
\text { biting in undocked pigs in } \\
\text { conventional farming }\end{array}$ & 442 & 2.5 & 1.5 & 31 & 3.8 & 1.7 & $p<0.001$ \\
\hline $\begin{array}{l}\text { Enrichment material in my pens helps } \\
\text { prevent tail biting }\end{array}$ & 480 & 3.5 & 1.7 & 33 & 5.1 & 1.1 & $p<0.001$ \\
\hline $\begin{array}{l}\text { It is better to dock all tails than to run the } \\
\text { risk of tail biting even if it concerns } \\
\text { just one bitten pig }\end{array}$ & 487 & 5 & 1.4 & 32 & 2.7 & 2 & $p<0.001$ \\
\hline $\begin{array}{l}\text { I know how to effectively treat tail biting } \\
\text { when it arises }\end{array}$ & 462 & 4.1 & 1.7 & 32 & 4.3 & 1.8 & Ns \\
\hline $\begin{array}{l}\text { A curly tail is important for a sustainable } \\
\text { pig husbandry and a good image }\end{array}$ & 484 & 2.7 & 1.7 & 33 & 5.4 & 1.1 & $p<0.001$ \\
\hline $\begin{array}{l}\text { Pig farmers should not be bothered with } \\
\text { the political or social desire to stop } \\
\text { docking. }\end{array}$ & 479 & 3.1 & 1.7 & 33 & 1.7 & 1 & $p<0.001$ \\
\hline $\begin{array}{l}\text { Farmers who attempt to stop docking } \\
\text { provide a service to the sector }\end{array}$ & 468 & 3.3 & 1.7 & 31 & 4.4 & 1.6 & $p<0.001$ \\
\hline $\begin{array}{l}\text { The conventional sector can stop } \\
\text { docking completely within the next } \\
15 \text { years }\end{array}$ & 464 & 2.5 & 1.6 & 28 & 3.7 & 1.8 & $p<0.001$ \\
\hline Docking tails is unpleasant work & 440 & 3.8 & 1.8 & 21 & 4.8 & 1.7 & $p<0.05$ \\
\hline
\end{tabular}

deviations and number of farms were $4.2 \pm 1.8, \mathrm{n}=23 ; 3.1 \pm 1.6, \mathrm{n}=157$; $3.3 \pm 1.7, \mathrm{n}=139 ; 3.2 \pm 1.7, \mathrm{n}=147 ; \mathrm{F}=2.7 ; p=0.048)$. No significant differences were found within the organic sector.

With respect to measures that can be taken when tail biting arises, conventional pig farmers believed that providing antibiotics to bitten animals $(p<0.001)$ and clipping or grinding the teeth of biting pigs $(p<0.01)$ was more useful, and providing extra enrichment or diversion material was less useful $(p<0.001)$ compared to the opinions of organic farmers. The opinions of conventional and organic farmers did not differ on other measures such as removing biters or bitten animals, improving stable climate, dimming light and using repellents. Whereas the two latter measures were among the least important (average score of about two on a scale from 1 to 4) notably the measure "dimming of light" was nevertheless still regarded as (very) useful by as many as 30-40\% of the conventional farmers. 
Within the sectors (conventional and organic farming) no differences were found between farm types.

Respondents were also asked which measures they took themselves when tail biting occurred on their farm. The measures "removing biters from the group" and "removing bitten animals from the group" were most popular among conventional pig farmers (39 and $37 \%$ respectively). The same was true for organic pig farmers (42 and $23 \%$ ), but they also frequently mentioned "providing extra enrichment and diversion material" or "tail biting does not occur" (32 and $26 \%$, compared to 19 and $18 \%$ in conventional farming). Improving climate was a measure more often taken by organic farmers $(13 \%)$ than conventional pig farmers $(8 \%)$. Clipping and grinding of teeth in case of a tail biting outbreak was done on 15.6 and $2.9 \%$ of the conventional farms respectively. On organic farms this was 6.5 and $3.2 \%$ respectively. Other less frequently used measures were application of repellents on pig tails (4.9 and $3.2 \%$ in conventional and organic farming respectively) and dimming of light (1.6 and $0 \%$ respectively). Some pig farmers reported taking "other" measures such as adjusting nutrition, adjusting pen density, or placing a rubber band or ring around the tail.

Table 3 shows farmer views on risk factors for tail biting. Farmers considered climate to be most important. Conventional pig farmers believed that "boredom" (enrichment materials) is less important and tail length more important than organic farmers did. Within the conventional sector significant differences of opinion were found between farmers on different farm types for risk factors such as "pen density," "suboptimal climate," "feeding system," and "runts or decreased growth" $(p<0.05)$. Sow farmers thought these risk factors were more important than farmers with closed farms or with growing/finishing farms. The risk factor "suboptimal climate" was significantly more important for sow farmers and breeding farms than growing/finishing farms. Within the organic sector growing/ finishing farmers believed that "race or breed" was significantly more important than farmers with closed farms (average scores and standard deviations for organic

Table 3 Opinions of pig farmers on the risk factors for tail biting (Avg, average scores, SD, standard deviations on a scale of $1-4$ with $1=$ very unimportant and $4=$ very important), Ns not significant

\begin{tabular}{|c|c|c|c|c|c|c|c|}
\hline \multirow[t]{2}{*}{ Risk factors } & \multicolumn{3}{|c|}{ Conventional } & \multicolumn{3}{|c|}{ Organic } & \multirow[t]{2}{*}{$p$} \\
\hline & $\mathrm{N}$ & Avg & SD & $\mathrm{N}$ & Avg & $\mathrm{SD}$ & \\
\hline Stable climate & 484 & 3.6 & 0.6 & 33 & 3.6 & 0.5 & Ns \\
\hline Stocking density & 479 & 3.3 & 0.7 & 33 & 3.6 & 0.6 & $p<0.05$ \\
\hline Suboptimal health & 481 & 3.3 & 0.6 & 33 & 3.2 & 0.7 & $p<0.10$ \\
\hline Rearing conditions & 452 & 3.1 & 0.7 & 32 & 2.8 & 0.7 & $p<0.10$ \\
\hline Tail length & 474 & 3.1 & 0.7 & 32 & 2 & 0.8 & $p<0.001$ \\
\hline Race or breed & 427 & 2.9 & 0.8 & 27 & 2.6 & 0.7 & $p<0.05$ \\
\hline Boredom of the animals & 461 & 2.8 & 0.8 & 33 & 3.3 & 0.8 & $p<0.001$ \\
\hline Runts or decreased growth & 475 & 2.8 & 0.9 & 30 & 2.7 & 0.9 & Ns \\
\hline Type of animal (gilts, barrows, boars) & 420 & 2.1 & 0.8 & 30 & 2.1 & 0.6 & Ns \\
\hline Feeding system (feed and feeding) & 441 & 2.5 & 0.9 & 31 & 2.3 & 0.6 & Ns \\
\hline
\end{tabular}


growing/finishing farms and closed farms were $3.1 \pm 0.7(\mathrm{n}=12)$ and $2.1 \pm 0.5$ $(\mathrm{n}=14)$ respectively, $\mathrm{F}=15.9 ; p=0.001)$. This was confirmed in our dataset in that a trend was found using a Chi-square test for more tail biting on growing/ fattening organic farms using Topigs 20 pigs.

Table 4 reflects the views of farmers on stopping tail docking in conventional pig farming. Not all statements applied to the organic sector because organic farmers do not dock tails, but when they did conventional and organic farmers often had different opinions. Conventional farmers would like to receive financial compensation from the government and were less likely to see market opportunities and less motivated to put effort into solving problems with tail biting and tail docking. Within the conventional sector farmers with different farm types had similar opinions. Organic growing/finishing farmers believed more than organic closed farms that the conventional sector should receive financial compensation from the government for the effort to stop tail docking (average scores and standard deviations were $3.9 \pm 1.7(\mathrm{n}=14)$ and $1.7 \pm 12(\mathrm{n}=17)$ respectively, $\mathrm{F}=18.2$; $p=0.000)$.

In the conventional sector, farms with an average size agreed more with the statement that straw can prevent tail biting problems in conventional farming compared to large and very large farms $(p=0.000)$. Small and average sized farms were more convinced that teeth clipping and grinding are useful measures to stop tail biting outbreaks $(p=0.042)$ and that boredom is an important risk factor for tail biting, than farmers on very large farms $(p=0.043)$. Very large farms were less

Table 4 Agreement of pig farmers with statements about conditions that must be met such that conventional farmers can stop tail docking ( Avg, average scores, SD, standard deviations, on a scale of 1-6 with $1=$ completely disagree and $6=$ completely agree)

\begin{tabular}{|c|c|c|c|c|c|c|c|}
\hline \multirow[t]{2}{*}{ Statement } & \multicolumn{3}{|c|}{ Conventional } & \multicolumn{3}{|c|}{ Organic } & \multirow[t]{2}{*}{$p$} \\
\hline & $\mathrm{n}$ & Avg & SD & $\mathrm{n}$ & Avg & SD & \\
\hline $\begin{array}{l}\text { Before I will stop docking, research must } \\
\text { first show that tail biting in practice } \\
\text { can be prevented in undocked animals }\end{array}$ & 479 & 5.4 & 1.2 & & & & \\
\hline $\begin{array}{l}\text { The conventional sector should put more } \\
\text { effort into the prevention of tail biting } \\
\text { and the stopping of tail docking }\end{array}$ & 477 & 3.8 & 1.7 & 31 & 4.9 & 1.2 & $p<0.001$ \\
\hline $\begin{array}{l}\text { The conventional sector should receive } \\
\text { financial compensation from the } \\
\text { government for the efforts taken to } \\
\text { stop tail docking }\end{array}$ & 474 & 3.8 & 2 & 33 & 2.8 & 1.9 & $p<0.01$ \\
\hline $\begin{array}{l}\text { Meat of undocked pigs should have } \\
\text { added value before I will stop docking }\end{array}$ & 472 & 3.8 & 1.9 & & & & \\
\hline $\begin{array}{l}\text { The abattoir should be less stringent in } \\
\text { monitoring pigs with bitten tails }\end{array}$ & 461 & 3.1 & 1.9 & 31 & 2.4 & 1.7 & $p<0.10$ \\
\hline $\begin{array}{l}\text { Not docking of tails is not a problem. It } \\
\text { offers market opportunities }\end{array}$ & 474 & 2.5 & 1.5 & 32 & 4.1 & 1.8 & $p<0.001$ \\
\hline $\begin{array}{l}\text { I must first build a new stable before I } \\
\text { can stop docking }\end{array}$ & 454 & 2.4 & 1.6 & & & & \\
\hline
\end{tabular}


likely to see market opportunities of keeping undocked pigs $(p=0.000)$ and were more likely to require additional payment for intact tails $(p=0.038)$ compared to small, average, and large farms. Very large farms were also more likely to think that the feeding system is an important risk factor for tail biting $(p=0.006)$.

In the organic sector large farms think repellents (anti-bite agents) on tails are a more effective measure against tail biting than small and average farms $(p=0.015)$. Organic farms with an average size thought suboptimal health is an important risk factor for tail biting, more than small farms do $(p=0.043)$. Small organic farms thought the race or breed is an important risk factor for tail biting, more than average farms do $(p=0.008)$.

Of the 487 conventional pig farmers who answered the question "Would you participate in a practical follow-up study on tail biting and tail docking?" $28.3 \%$ $(n=138)$ answered affirmatively. These farmers distinguish themselves on several respects from pig farmers who declined. Pig farmers who were interested in a follow-up study agreed more with the statements: "Docking is painful for piglets" $(p=0.006)$, "A curl in the tail is important for a sustainable pig husbandry and a good image" ( $p=0.004)$, "Farmers who attempt to stop docking provide a service to the sector" ( $p=0.031)$ and "The conventional sector should put more effort into the prevention of tail biting and the stopping of tail docking" $(p=0.000)$. Pig farmers who were willing to participate in a follow-up study believed that removing bitten animals from the group was a less useful measure than respondents who did not want to participate $(p=0.011)$. Between these two groups no difference was found in the occurrence of tail biting on their farms and there was no relation with farm type or farm size.

\section{Discussion}

Tail biting causes welfare and health problems for the animals, economic losses for the farmers and a reduction in job satisfaction for the pig farmer (Bracke et al. 2004; Workel et al. 2007). Tail docking is routinely performed to minimize the risk of tail biting, but this practice does not solve the problem. In fact it only aggravates moral concern about pig farming (Harrison 1964; Singer 1975). Tail docking is not only a painful procedure, is also reduces the pigs' integrity. It is also not compatible with the Dutch Ministry of Agriculture, Nature and Food Quality's objective of a fully sustainable livestock sector without mutilations by 2023 (LNV 2007). Therefore it is important to find ways to reduce tail docking. Other housing or adjustment of current housing systems seem to offer opportunities (Moinard et al. 2003). Pig farmers play a crucial role in implementing solutions on the farm but they have to be prepared to take steps. The survey reported here was conducted to find out what the perceptions and attitudes of Dutch pig farmers are towards tail biting and tail docking.

To a large extent conventional farmers seem to prefer to deny that there are important welfare problems with pig farming, despite regular attention to pig welfare in the media. This may be related to the pig farmers' view that welfare is defined by proper health and production results (te Velde et al. 2002; Lassen et al. 
2006; Bock and Van Huik 2007; De Rooij et al. 2010). This is in line with our finding that health issues were high on the farmers' welfare priority list (third, after space and biting). Of all welfare issues identified, "biting" was mentioned most frequently. This confirms that abnormal harmful behavior, including not only tail biting but especially also ear biting, is perceived to be a main pig welfare issue (see also Spoolder et al. 2011).

As many as 35-50\% of conventional pig farmers and over $50 \%$ of the organic farmers reported that tail biting did not occur on their farms. Remarkably, the distribution of tail biting was not normal, but rather bi-modal (see Fig. 1). This pattern was also found by Taylor et al. (personal communication) who plotted tail biting frequencies in 172 (partly repeated) farm visits in the UK. Perhaps this distribution relates to the fact that tail biting occurs in "outbreaks," more or less like disease outbreaks do (see also Bracke 2008; Zonderland 2010).

Two-thirds of the farmers reported no recollection of having tried to stop tail docking. This appears to be in violation of EC Directive 2001/93 (Art. 8 of the Appendix), which states that "tail docking [...] must [not] be carried out routinely but only where there is evidence that injuries to [...] other pigs' [...] tails have occurred. [...]Before carrying out these procedures, other measures shall be taken to prevent tail biting and other vices taking into account environment and stocking densities." Limited farmer compliance is also supported by the finding that farmers who did have experience with undocked pigs reported all kinds of frequency levels of subsequent tail biting in these undocked pigs (Fig. 2).

A further point related to compliance concerns the illegal practice of cutting the front teeth in case of a tail biting outbreak. This is done to prevent (potential) biters from causing further damage. In fact this is an even more crude measure against tail biting than tail docking, and one that should raise substantial moral concern. The results of this study led the Party for the Animals to ask questions to the Secretary of State who is responsible for pig farming. In response, the Ministry decided to initiate a route plan to ban tail docking and teeth cutting in the future (EL\&I 2010, 2011).

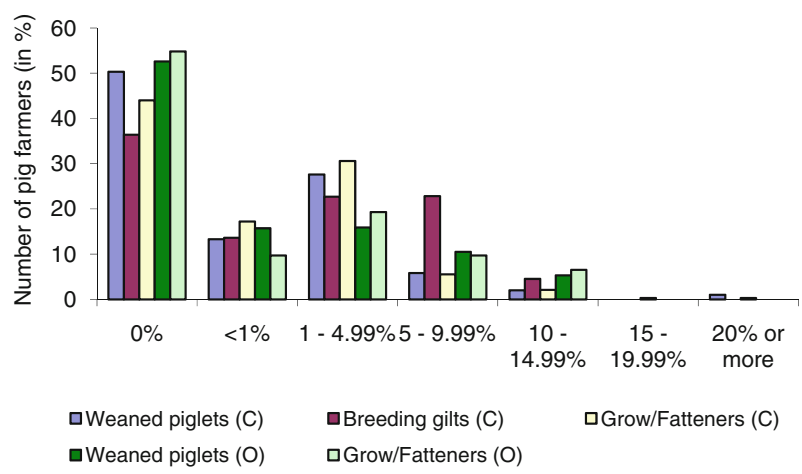

Fig. 1 Frequency distribution of tail biting in various types of pig on conventional (C) and organic (O) farms 


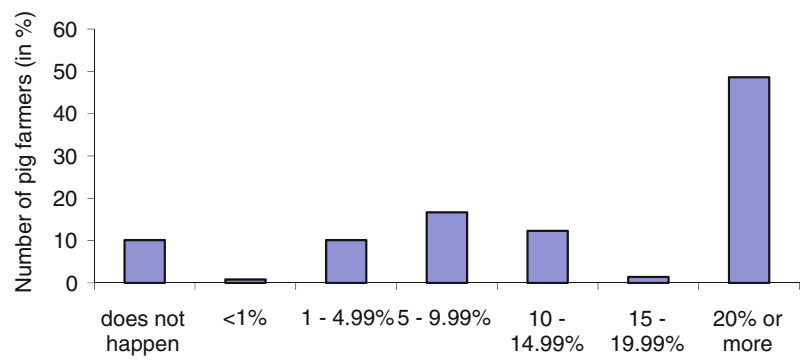

Fig. 2 Reported frequency distribution of tail biting in conventional farms when tail docking was not practiced

According to conventional farmers. teeth cutting or grinding was considered to be reasonably valuable to combat tail biting (score 2.8 on a scale from 1 to 4 ), and organic farmers were significantly $(p<0.01)$ less convinced that this was true (average 2.1). Overall, 65-70\% of farmers considered that cutting the teeth was useful or very useful.

On average $15.6 \%$ of conventional farmers reported cutting teeth themselves in case of tail biting. This is probably an under-representation of reality, because at least some farmers will have been aware that they were reporting an illegal practice. Out of 23 breeding farms participating in our survey $0 \%$ reported this measure, while $18.1 \%$ of closed farms did so. The low percentage in breeding farms is probably due to the fact that the questionnaire focused on young breeding gilts (until $25 \mathrm{~kg}$ ), rather than on the older breeding gilts, where tail biting is more of a problem (due to, among others, restricted feeding). In addition, farmers of breeding gilts are more experienced in "proper" communication (as their business entails selling gilts to other farmers). The percentages of teeth grinding are much lower $(2.9 \%)$ than teeth cutting $(15.5 \%)$ as the former is done mainly on young piglets in the farrowing pen in case of damage to the udder and it is not as practical in tail biting outbreaks in older, heavier pigs.

Both in weaned piglets and in older growing/fattening pigs, farmers that had reported less tail biting on their farm $(<1 \%)$ reported lower levels of teeth cutting (on average about $15 \%$ ), while this percentage increased to 34 and $41 \%$ for weaners and growers/finishers respectively when farmers had reported higher levels of tail biting $(\geq 5 \%)$. These findings from our survey confirm that the issue regarding teeth cutting should be taken seriously, and that the moral problems related to barren housing of pigs do not only extend to tail biting and tail docking, but also to pain involved due to the farmers' attempts to solve tail biting outbreaks using teeth cutting.

Another point concerns the use of enrichment materials. EC Directive 2001/93 prescribes that pigs must have permanent access to a sufficient quantity of material to enable proper investigation and manipulation activities, such as straw, hay, wood, sawdust, mushroom compost, peat, or a mixture of such. Whereas organic farmers provided straw, saw dust, or wood shavings (88-100\% of farms), conventional farmers provided a chain (52-63\% of the farms depending on the farm type) and/or 
a hanging rubber or plastic ball (22-30\% of the farms), rather than straw, sawdust or wood shavings (2-3\% of the farms). Several scientific publications indicate that toys are inadequate enrichment materials for pigs (EFSA 2007b; Spoolder et al. 2011). By contrast, studies have shown that the risk of tail biting can be reduced substantially when (long) straw is provided once or twice daily (Moinard et al. 2003; Zonderland et al. 2008).

According to the PIGTAIL model (Bracke et al. 2004) and EFSA (2007a) main risk factors for tail biting include tail status (tail length and whether or not tails are wounded), the absence of straw, other substrate or enrichment material, race/breed, and elevated stocking densities. To some extent these factors are also mentioned by farmers. With respect to genetics it is relevant to note that it may be both a cause (due to selection for lean meat and individual selection of animals that grow fast at the expense of their pen mates, e.g., due to tail biting) and also a potential solution for tail biting problems (by selecting docile pigs that are less inclined to show tail or ear biting).

Most notably, however, climate is regarded by conventional and organic pig farmers as most important, while this has been assessed as a much lower risk factor in the scientific studies mentioned above (see esp. EFSA 2007a). One possible reason for this may be that climatic effects are much harder to identify scientifically than factors such as straw, stocking density, and tail status (because the former act at the level of the pig unit (often containing 5-15 pens), whereas the latter act at pen level). Another possible reason is that farmers are used to controlling climate much more than providing substrates such as straw, which they believe are incompatible with their slurry-based systems (which may get blocked by straw).

Conventional pig farmers' views on tail docking, tail biting, and enrichment may arise from "dissonance reduction" (te Velde et al. 2002). In that case unwanted information was played down (e.g., about the painfulness of docking tails and the value of enrichment materials and curly tails) and advantages were emphasized (tail docking is necessary). Bigger farms also seem to display more dissonance reduction because they tend to deny more that boredom is an important risk factor for tail biting.

The results of our survey suggest that especially among the conventional farmers it is not clear who should take responsibility to stop docking. This is in agreement with results of de Lauwere et al. (2007), who found that especially conventional pig farmers believe that the responsibility for proper animal welfare should be with society. The conventional farmers in our survey showed average agreement (score 3.3 on a scale from 1 to 6 ) on the statement 'Farmers who attempt to stop docking provide a service to the sector." However, underlying this score about $20 \%$ of the farmers totally disagreed with the statement. In fact, a substantial number of farmers may be motivated to discourage other farmers to try to reduce the need for tail docking.

Results from this survey, however, also provide clues as to how problems with enrichment, tail docking, tail biting and teeth cutting can be solved. These solutions are in line with a newly developed method, IND (Intelligent Natural Design, Bracke 2010). The method entails designing a process of "natural selection" for reducing welfare problems using available scientific and practical knowledge. In this method 
it is important that pig farmers are given sufficient ethical room for maneuver (e.g., Korthals 2008; Driessen 2007; Driessen et al. 2010) to apply technological innovations that may solve the problem. To this end farmers should be encouraged to learn from each other and exchange experiences (social learning, Rotmans 2003), and other stakeholders in the production chain should also be involved more actively (Grin and van de Graaf 1996).

Our study shows that there should be room for maneuver, i.e., to reduce the need for tail docking, since as many as 35-50\% of conventional farmers report no tail biting on their farm and since average tail biting prevalences on conventional farms are relatively low (1.1-1.3\% for sow, closed and growing/fattening farms; $2.2 \%$ for breeding farms).

Secondly, while conventional farmers in general relatively disagree that they can stop tail docking completely within 15 years (average score 2.5), about $20 \%$ of them give a score 4,5 or 6 , i.e., they agree (completely) that stopping tail docking is feasible. Furthermore, on the whole conventional farmers didn't think they will need to build another stable before they can stop tail docking (average score 2.4 on a 1-6 scale).

The problems addressed here clearly relate to both legal requirements and market forces. With respect to legal requirements, possible solutions may be found in enhanced compliance and (relatively moderate) reformulations of existing regulations. For example, it could be demanded that only enrichment materials may be used that have been shown to reduce tail biting, or higher levels of enrichment may be required in pens containing pigs that are suffering or that have suffered from tail or ear biting problems in the past. Another substantial contribution could be made by market forces, e.g., when slaughterhouses would motivate farmers to deliver pigs with intact tails, ears (and teeth). Finally, farmers may be supported financially to pay for better enrichment materials (such as straw) by encouraging welfare measures that increase production efficiency, such as keeping intact boars (rather than castrated barrows). Hence, an integrated approach to solving the complex problem of pig welfare related to enrichment, tail biting, and tail docking is called for.

Acknowledgments We would like to thank the anonymous reviewers of an earlier version of this paper for their helpful comments and the former Ministry of Agriculture, Nature and Food Quality for financing the research.

Open Access This article is distributed under the terms of the Creative Commons Attribution License which permits any use, distribution, and reproduction in any medium, provided the original author(s) and the source are credited.

\section{Appendix: Questionnaire (in Dutch)}

Vragenlijst ten behoeve van de telefonische enquête over de wijze waarop gangbare en biologische varkenshouders tegen staartbijten en staartcouperen aankijken.

Inleiding 
Goede...DAG. U spreekt met ...van Wageningen Universiteit. Spreek ik met het bedrijfshoofd?

Wij zijn voor LNV bezig met een kort onderzoek over staartbijten en staartcouperen.

Schikt het $\mathrm{u}$ nu om in maximaal 10 minuten enkele vragen te beantwoorden?

$1 \mathrm{Ja}$

2 Nee niet nu, maar op ander tijdstip

3 Nee, wil niet meewerken

Vragen over non-respons

Mag ik vragen waarom u niet mee wilt werken?

1 Couperen van staarten geen belangrijk onderwerp

2 Couperen van staarten een te lastig/ingewikkeld onderwerp

3 Anders

4 Wil niet zeggen

Anders?

Reden nonrespons

1 Geen varkenshouder, bedrijf gestopt, gaat stoppen

2 Weigert medewerking

3 Medewerking niet mogelijk binnen onderzoeksperiode

4 Gepensioneerd

5 Enquête duurde te lang

6 Geen of fout tel. nr.

7 Alleen bereikbaar op 06-nummer

8 Is al gebeld

9 Andere reden

Eerst enkele algemene vragen over uw bedrijf.

1. Heeft u een gangbaar of een biologisch bedrijf?

1. Gangbaar

2. Biologisch

3. Beide

4. In overgang van gangbaar naar biologisch

5. Wil niet zeggen

2. Is dit bedrijf een gesloten varkensbedrijf, een fokzeugenbedrijf, een vleesvarkensbedrijf of een opfokbedrijf?

1. Fokzeugen/vermeerdering

2. (Half) Gesloten bedrijf

3. Vleesvarkens bedrijf

4. Sub-, top-, opfokbedrijf

5. Wil niet zeggen

3. Hoeveel zeugen heeft $u$ ?

\{Vraag voor fokbedrijven

4. Hoeveel opfokgelten tot 100 kilogram heeft $u$ ?

\{Vraag voor gesloten bedrijven en vleesvarkensbedrijven

5. Hoeveel vleesvarkens van 25 tot 110 kilogram (= 10 weken tot 6 maanden) heeft $\mathrm{u}$ ?

6. Als u uw kengetallen vergelijkt met die van uw collega's. 
Zijn uw bedrijfsresultaten dan:

1. Minder dan gemiddeld

2. Gemiddeld

3. Meer dan gemiddeld

4. Of ver boven gemiddeld

5. Weet niet

6 . Wil niet zeggen

\{Vraag voor vermeerderingsbedrijven en gesloten bedrijven

7. Wat is het ras of de kruising van uw gespeende biggen, die vleesvarken worden?

\{Vraag voor fokbedrijven\}

8. Wat is het ras of de kruising van uw opfokgelten?

\{Vraag voor gesloten bedrijven en vleesvarkensbedrijven\}

9. Wat is het ras of de kruising van uw vleesvarkens?

\{Vraag voor vermeerderingsbedrijven en gesloten bedrijven\}

10.Wat is het meest voorkomende aantal dieren per hok bij de gespeende biggen van 4 tot 10 weken?

\{Vraag voor fokbedrijven\}

11.Wat is het meest voorkomende aantal dieren per hok bij de jonge opfokgelten van 4 tot 10 weken?

\{Vraag voor gesloten bedrijven en vleesvarkensbedrijven

12.Wat is het meest voorkomende aantal dieren per hok bij de vleesvarkens van

25 tot 110 kilogram?

\{Vraag voor vermeerderingsbedrijven en gesloten bedrijven

13.Welk verrijkings- of afleidingsmateriaal heeft $u$ in de hokken van de gespeende biggen?

1. Ketting

2. Hangende rubber of plastic bal

3. Bal of jerrycan los in het hok

4. Ketting met plastic slang eromheen

5. Overig plastic of rubber materiaal (bijvoorbeeld bite rite)

6. Stuk hout of touw

7. Stro, zaagsel of houtkrullen

8. Ruwvoer

9. Anders

10. Ik heb geen verrijkingsmateriaal

11. Wil niet zeggen

52

12. Weet niet

14.Anders?

\{Vraag voor fokbedrijven

15.Welk verrijkings- of afleidingsmateriaal heeft $u$ in de hokken van de opfokgelten?

Maximaal 12 antwoorden mogelijk

1. Ketting

2. Hangende rubber of plastic bal 
3. Bal of jerrycan los in het hok

4. Ketting met plastic slang eromheen

5. Overig plastic of rubber materiaal (bijvoorbeeld bite rite)

6. Stuk hout of touw

7. Stro, zaagsel of houtkrullen

8. Ruwvoer

9. Anders

10. Ik heb geen verrijkingsmateriaal

11. Wil niet zeggen

12. Weet niet

16.Anders?

\{Vraag voor gesloten bedrijven en vleesvarkensbedrijven

17.Welk verrijkings- of afleidingsmateriaal heeft $u$ in de hokken van de vleesvarkens?

1. Ketting

2. Hangende rubber of plastic bal

3. Bal of jerrycan los in het hok

4. Ketting met plastic slang eromheen

5. Overig plastic of rubber materiaal (bijvoorbeeld bite rite)

6. Stuk hout of touw

7. Stro, zaagsel of houtkrullen

8. Ruwvoer

9. Anders

10. Ik heb geen verrijkingsmateriaal

11. Wil niet zeggen

12. Weet niet

18.Anders?

19.Wat is volgens $u$ het belangrijkste probleem op het gebied van dierenwelzijn in de varkenshouderij?

$\mathrm{Nu}$ een aantal stellingen over staartcouperen en staartbijten. Kunt u steeds op een schaal van 1 tot 6 aangeven in hoeverre $u$ het eens bent met de stelling? Een 1 is helemaal mee oneens en een 6 is helemaal mee eens.

20.Staartbijten is een belangrijk welzijnsprobleem voor mijn dieren. In hoeverre bent $\mathrm{u}$ het daar mee eens?

21.Couperen van staarten is vervelend werk. In hoeverre bent $u$ het daar mee eens?

22.Couperen is noodzakelijk om staartbijten te voorkomen. In hoeverre bent $u$ het daar mee eens?

23.Er is géén andere oplossing dan couperen om staartbijten tegen te gaan. In hoeverre bent $\mathrm{u}$ het daar mee eens?

24.Couperen is pijnlijk voor biggen. In hoeverre bent $\mathrm{u}$ het daar mee eens?

25.Met stro kun je problemen met staartbijten bij ongecoupeerde varkens in de gangbare varkenshouderij voorkomen. In hoeverre bent u het daar mee eens?

26. Het afleidingsmateriaal in mijn varkenshokken helpt staartbijten te voorkomen. In hoeverre bent $\mathrm{u}$ het daar mee eens? 
27.Het is beter om alle staarten te couperen dan om het risico op staartbijten te lopen, ook al gaat het maar om één gebeten varken. In hoeverre bent $u$ het daar mee eens?

28.Ik weet hoe ik staartbijten effectief kan behandelen als het optreedt. In hoeverre bent $\mathrm{u}$ het daar mee eens?

29.Een krul in de staart is belangrijk voor een duurzame varkenshouderij en een goed imago. In hoeverre bent $u$ het daar mee eens

30.Varkenshouders moeten zich niets aantrekken van de politieke of maatschappelijke wens om te stoppen met couperen. In hoeverre bent $u$ het daar mee eens?

31.Varkenshouders die proberen te stoppen met couperen bewijzen de sector een dienst. In hoeverre bent $\mathrm{u}$ het daar mee eens?

32.De gangbare sector kan binnen 15 jaar volledig gestopt zijn met couperen. In hoeverre bent $\mathrm{u}$ het daar mee eens?

\{Vraag voor vermeerderingsbedrijven en gesloten bedrijven\}

33. Welk deel van de varkensstaart laat $\mathrm{u}$ aan het varken zitten bij het staartcouperen van biggen die vleesvarken worden? Is dat :

1. Niets

2. Een kwart

3. Een derde

4. De helft

5. Of twee derde

6. Anders

7. Coupeert geen staarten

8. Weet niet

9. Wil niet zeggen

34.Anders?

\{Vraag voor fokbedrijven

35.Welk deel van de varkensstaart laat $\mathrm{u}$ aan het varken zitten bij het staartcouperen

van biggen die opfokgelt worden?

Is dat :

1. Niets

2. Een kwart

3. Een derde

4. De helft

5. Of twee derde

6. Anders

7. Coupeert geen staarten

8. Weet niet

9. Wil niet zeggen

36.Anders?

37.Wanneer is er in uw ogen sprake van een ernstige vorm van staartbijten?

1. Eén dier met bijtpuntjes (tandafdrukken in de staart)

2. Enkele dieren met bijtpuntjes

3. Eén dier met een staartverwonding 
4. Enkele dieren met staartverwonding

5. Eén dier met dikke, ontstoken staart

6. Enkele dieren met dikke ontstoken staart

7. Anders

8. Weet niet

9. Wil niet zeggen

38.Anders?

\{Vragen voor vermeerderingsbedrijven en gesloten bedrijven

39.Bij ongeveer hoeveel procent van uw gespeende biggen van 4 tot 10 weken heeft $\mathrm{u}$ staartbijten gezien in de vorm van staartwonden tussen opleg en afleveren?

40.Op hoeveel weken na spenen treedt staartbijten bij gespeende biggen meestal op?

\{Vragen voor gesloten bedrijven en vleesvarkensbedrijven \}

41.Bij ongeveer hoeveel procent van uw vleesvarkens na opleg heeft $u$ staartbijten gezien in de vorm van staartwonden?

42.Op hoeveel weken na opleg treedt staartbijten bij vleesvarkens meestal op? \{Vragen voor fokbedrijven

43.Bij ongeveer hoeveel procent van uw jonge opfokgelten van 4 tot 10 weken heeft $\mathrm{u}$ staartbijten gezien in de vorm van staartwonden?

44.Op hoeveel weken na spenen treedt staartbijten bij jonge opfokgelten meestal op?

\{Vraag $45 \mathrm{t} / \mathrm{m} 48$ alleen voor niet-biologische bedrijven

45.Heeft $\mathrm{u}$ in het verleden wel eens geprobeerd ongecoupeerde varkens met lange staarten te houden?

1. Ja

2. Nee

3. Weet niet/geen mening

46.Bij ongeveer hoeveel procent van deze dieren trad toen staartbijten op?

47.Heeft $\mathrm{u}$ in het verleden wel eens geprobeerd minder kort te couperen?

1. Ja

2. Nee

3. Weet niet/geen mening

48.Waren uw ervaringen positief of negatief?

1. Zeer positief

2. Positief

3. Neutraal

4. Negatief

5. Zeer negatief

6. Weet niet

7. Wil niet zeggen

\{Dit blok krijgt iedereen $\}$

Ik noem nu een aantal mogelijke maatregelen die u kunt nemen op uw bedrijf als staartbijten voorkomt. Kunt u steeds aangeven in hoeverre $\mathrm{u}$ een maatregel al of niet zinvol vindt, ook als u deze maatregel zelf al neemt?

49.Gebeten dieren uit de groep halen. 
1. Absoluut niet zinvol

2. Weinig zinvol

3. Enigszins zinvol

4. Zeer zinvol

5. Weet niet

6 . Wil niet zeggen

50.Bijters uit de groep halen.

51.Tanden knippen of slijpen.

52.Antibijt middel op de staarten van de varkens doen.

53.Antibioticum geven aan de gebeten dieren.

54.Het stalklimaat verbeteren

55.Het licht dimmen of uitzetten.

56.Extra afleidingsmateriaal/verrijking verstrekken.

57. Welke maatregelen neemt u zelf als staartbijten optreedt?

1. Staartbijten komt nooit voor

2. Neem geen maatregelen

3. Gebeten dieren uit de groep halen

4. Bijters uit de groep halen

5. Tanden knippen

6. Tanden slijpen

7. Antibijt middel op de staarten van de varkens doen

8. Antibioticum geven aan de gebeten dieren

9. Stalklimaat verbeteren

10. Licht dimmen of uitzetten

11. Extra afleidingsmateriaal/verrijking verstrekken

12. Anders

13. Weet niet

14. Wil niet zeggen

58.Anders?

Ik noem nu een aantal factoren die een rol kunnen spelen bij het ontstaan van staartbijten. Kunt u steeds aangeven hoe belangrijk een risicofactor, volgens u, is?

59. Het stalklimaat.

1. Zeer onbelangrijk

2. Onbelangrijk

3. Belangrijk

4. Zeer belangrijk

5. Weet niet

6 . Wil niet zeggen

60. Verveling bij dieren.

61.De hokbezetting.

62.Het type dier, dus gelten, borgen of beren.

63.De staartlengte.

64.Een suboptimale gezondheid

65.Het voersysteem.

66.Het ras of kruising 
67.De opfokcondities.

68.Achterblijvers of een slechte groei.

$\mathrm{Nu}$ weer een aantal stellingen. Kunt $\mathrm{u}$ weer op een schaal van 1 tot 6 aangeven in hoeverre $u$ het eens bent met de stelling? Een 1 is helemaal mee oneens en een 6 is helemaal mee eens.

69.De gangbare sector moet financieel gecompenseerd worden door de overheid voor inspanningen die ze moeten leveren om staartcouperen achterwege te laten. \{Alleen voor niet-biologische bedrijven

70.Onderzoek moet eerst aantonen dat het staartbijten in de praktijk voorkomen kan worden bij ongecoupeerde dieren, voordat ik ga stoppen.

71.Ik moet eerst een andere stal bouwen of de stal verbouwen, voordat ik kan stoppen met staartcouperen.

72.De slachterij moet minder streng controleren op varkens met aangebeten staarten.

73.Vlees van ongecoupeerde varkens moet een meerprijs opleveren, voordat ik ga stoppen met couperen.

74.De gangbare sector moet haar schouders zetten onder het probleem van staartbijten en het couperen van biggen.

75.Het niet couperen van staarten is geen probleem. Het biedt juist marktkansen. 76.Tot slot de laatste vraag. Zou u mee willen doen aan een praktijkonderzoek naar staartbijten en couperen om te zien of het onder begeleiding mogelijk is om op een verantwoorde wijze het couperen van varkensstaarten terug te brengen?

1. Ja

2. Nee

\section{References}

Bock, B. B., \& van Huik, M. M. (2007). Animal welfare: The attitudes and behavior of European pig farmers. British Food Journal, 109, 931-944.

Bovenkerk, B., Brom, F. W. A., \& Van den Bergh, B. (2002). Brave new birds: The use of 'Animal Integrity' in animal ethics. Hastings Center Report, 32, 16-22.

Bracke, M. B. M. (2008). RICHPIG: A semantic model to assess enrichment materials for pigs. Animal Welfare, 17, 289-304.

Bracke, M. B. M. (2010). Towards long(er) pig tails: New strategy to solve animal welfare problems. In L. Lidfors, H. Blokhuis, \& L. Keeling (Eds.), Proceedings of the 44th congress of the ISAE, August 4-7 2010 (p. 135). Wageningen: Wageningen Academic Publishers. (Poster, ISAE 2010, Uppsala, Sweden, Aug 4-7).

Bracke, M. B. M. (Editor) (2011). Verbeteren welzijnsprestaties in de biologische veehouderij: Korte termijn speerpunten en aanzet tot lange termijn visie. (Improving welfare performance in organic farming: Short term priorities and initiation of a long term vision). Report 479. Wageningen Livestock Research, Lelystad, The Netherlands. Accessed 6 Dec 2011. Available at http://edepot.wur.nl/187488.

Bracke, M. B. M., Hulsegge, B., Keeling, L., \& Blokhuis, H. J. (2004). Decision support system with semantic model to assess the risk of tail biting in pigs, 1. Modelling. Applied Animal Behavior Science, 87, 31-44.

De Lauwere, C., de Rooij, S., \& van der Ploeg, J. D. (2007). Understanding farmers' values. In W. Zollitsch, C. Winckler, S. Waiblinger \& A. Haslberger (Eds.), Sustainable food production and 
ethics (pp. 198-203). Preprints of the 7th congress of the European Society for Agricultural and Food Ethics. EURSAFE 2007, Vienna, 2007.

De Lauwere, C., Hoogendam, K., Zonderland, J., \& Bracke, M. (2009). Stoppen met couperen? Varkenshouders over staartbijten en staartcouperen. LEI rapport 2009-97, LEI, The Haag.

De Rooij, S. J. G., de Lauwere, C. C., \& van der Ploeg, J. D. (2010). Entrapped in group solidarity? Animal welfare, the ethical positions of farmers and the difficult search for alternatives. Journal of Environmental Policy and Planning, 12, 341-361.

Done, S. H., Guise, J., \& Chennels, D. (2003). Tail biting and tail docking in pigs. The Pig Journal, 51, $136-154$.

Driessen, C. (2007). Stacking pigs: Dutch pig tower debates and the changing nature of ethical livestock production. In W. Zollitsch, C. Winckler, S. Waiblinger, \& A. Haslberger (Eds.), Sustainable food production and ethics (pp. 219-233). Wageningen, The Netherlands: Wageningen Academic Publishers.

Driessen, C., Bracke, M. B. M., \& Copier, M. (2010). Designing a computer game for pigs: To explore and redefine the interface between animal welfare, science and ethics. In C. M. R. Casabona, L. E. San Epifanio, \& A. E. Cirión (Eds.), Global food security: Ethical and legal challenges (pp. 323-328). Wageningen, The Netherlands: Wageningen Academic Publishers.

EFSA. (2007a). Scientific report on the risks associated with tail biting in pigs and possible means to reduce the need for tail docking considering the different housing and husbandry systems. Appendix to the EFSA Journal, 611, 1-13.

EFSA. (2007b). Animal health and welfare in fattening pigs in relation to housing and husbandry. Scientific opinion of the panel on animal health and welfare. The EFSA Journal, 564, 1-14.

EL\&I. (2010). Kamervragen over het knippen van tanden als maatregel tegen bijterij bij varkens. Brief van 9 Nov 2010 aan de Voorzitter van de Tweede Kamer der Staten-Generaal. Den Haag. Available at http://www.rijksoverheid.nl/ministeries/eleni/documenten-en-publicaties/kamerstukken/2010/11/ 10/kamervragen-over-het-knippen-van-tanden-als-maatregel-tegen-bijterij-bij-varkens.html.

EL\&I. (2011). Kamervragen inzake tandenknippen varkenshouderij. Brief van 18 Januari 2011 aan de Voorzitter van de Tweede Kamer der Staten-Generaal. Beschikbaar op http://www.rijksoverheid.nl/ ministeries/eleni/documenten-en-publicaties/kamerstukken/2011/01/18/antwoord-kamervrageninzake-tandenknippen-varkenshouderij.html.

Grin, J., \& van de Graaf, H. (1996). Technology assessment as learning. Science, Technology, and Human Values, 21, 72-99.

Harrison, R. (1964). Animal machines. London: Vincent Stuart Ltd.

Herskin, M. S., Holm, B., Waag, R., Thodberg, K., Jensen, H. E. (2010). Effects of pig tail docking and docking length on the formation of neuromas. In Kehlet, H., Staehelin Jensen, T., Svejgaard, A., Krogsgaard-Larsen, P., Acute pain-pathophysiology and risk factors for chronification (p. 9). Benzon Symposium no, 57, Copenhagen. Accessed 25 Feb 2011. Available at http://www. benzon-symposia.dk/s57-abstract-www.pdf.

Hopster, H., Groot Bruinderink, G. W. T. A., \& Bracke, M. B. M. (2011). Policy options for the improvement of the welfare of animals in the province of Zuid-Holland. Report 535. Wageningen Livestock Research, Lelystad. Available at http://edepot.wur.nl/192550.

Korthals, M. (2008). Ethical rooms for manoeuvre and their prospects vis-à-vis the current ethical food policies in Europe. Journal of Agricultural and Environmental Ethics, 21, 249-273.

Lassen, J., Sandøe, P., \& Forkman, B. (2006). Happy pigs are dirty! Conflicting perspectives on animal welfare. Livestock Science, 103, 221-230.

LNV. (2007). Nota Dierenwelzijn. Ministerie van Landbouw, Natuur en Voedselkwaliteit, Den Haag.

Moinard, C., Mendl, M., Nicol, C. J., \& Green, L. E. (2003). A case control study of on-farm risk factors for tail biting in pigs. Applied Animal Behaviour Science, 81, 333-355.

Rotgers, G., \& Visser, F. (2011). Registratie biologische veebedrijven niet op orde. [Registration organic farms not in order]. V-focus, 12, 13-15.

Rotmans, J. (2003). Transitiemanagement. Sleutel voor een duurzame samenleving. Koninklijke van Gorcum, Assen.

Schröder-Petersen, D. L., \& Simonsen, H. B. (2001). Review tail biting in pigs. The Veterinary Journal, 162, 196-210.

Simonsen, H. B., Klinken, L., \& Bindseil, E. (1991). Histopathology of intact and docked pigtails. British Veterinary Journal, 147, 407-412.

Singer, P. (1975). Animal liberation: A new ethics for our treatment of animals. New York: New York Review of Books. 
Spoolder, H., Bracke, M., Mueller-Graf, C., \& Edwards, S. (Eds.), (2011). Scientific report updating the EFSA opinions on the welfare of pigs-Report 2-Update of animal health and welfare aspects in relation to housing and husbandry of weaned, growing and fattening pigs, including space, floors, tail biting and tail docking-Consisting of 3 sub-reports corresponding to 3 EFSA's scientific opinions to be updated-31 May 2011. Available at http://www.efsa.europa.eu/en/supporting/ doc/181e.pdf. Accessed 31 Aug 2011.

SPSS. (2008). SPSS 15.0.1 for Windows Pach. Chicago: SPSS inc.

te Velde, H., Aarts, N., \& van Woerkum, C. (2002). Dealing with ambivalence: Farmers' and consumers' perceptions of animal welfare in livestock breeding. Journal of Agricultural and Environmental Ethics, 15, 203-219.

Thodberg, K., Jensen, K. H., \& Jørgensen, E. (2010). The risk of tail biting in relation to level of taildocking. In Proceeding of the 44th congress of the ISAE (p. 91). Sweden: Uppsala.

Weary, D. M., \& Fraser, D. (2004). Rethinking painful management practices. In G. J. Benson \& B. E. Rollin (Eds.), The well-being of farm animals: Challenges and solutions (1st ed., pp. 325-338). Ames IA: Blackwell.

Workel, L., Zonderland, J. J., \& Bracke, M. B. M. (2007). Couperen van varkensstaarten-report of a workshop. Lelystad: ASG.

Zonderland, J. J. (2010). Talking tails-quantifying the development of tail biting in pigs. PhD Thesis, Wageningen: Wageningen University.

Zonderland, J. J., \& Bracke, M. B. M. (2008). Interviews met potentiële klankbordgroepleden voor het project 'Stoppen met staartcouperen bij varkens'. Lelystad: Rapport ASG. 2008.

Zonderland, J. J., Bosma B., \& Hoste, R., (2011). Financiële consequenties van staartbijten bij varkens (Financial consequences of tail biting in pigs). Report 543. Wageningen Lelystad, The Netherlands: Livestock Research. Available at http://edepot.wur.nl/188443. Accessed 13 Dec 2011.

Zonderland, J. J., Wolthuis-Fillerup, M., van Reenen, C. G., Bracke, M. B. M., Kemp, B., den Hartog, L. A., et al. (2008). Prevention and treatment of tail biting in weaned piglets. Applied Animal Behavior Science, 110, 269-281. 